Environment Conservation Journal 16(1\&2) 179-186, 2016

ISSN 0972-3099 (Print) 2278-5124 (Online)

Abstracted and Indexed

\title{
Ecological damage in the vicinity of two industrial areas of Uttarakhand
}

\author{
Shweta Ranghar and Mamta Baunthiyal $\bowtie$
}

Received 21.03.2016

Accepted:29.04.2016

\begin{abstract}
Pollutants from industries can directly affect plants via leaves or indirectly via soil and water. A study was carried near industrial areas of Dehradun and Kotdwara cities of Uttarakhand to evaluate the risk of pollution on water, soil and natural vegetation near industrial area. Water samples were checked for Total dissolved solids (TDS), Turbidity, pH, Alkalinity, Fluoride, Chloride and Total hardness. The soil sample was checked for pH and number of microorganism. The natural vegetation was checked for various biochemical parameters. The estimation of chlorophyll (a and b), Carotenoid, pheophytin (a and b), protein, peroxidase activity were studied in the species such as Tagetes, Brassica, Rosa, Morinda and Murraya. Result were obtained and compared with the control ( $2 \mathrm{kms}$ apart from sampling area).The study concluded that industrial area may be polluted with organic pollutants which resulted in change in some chemical parameters of water mainly total hardness and change in soil $\mathrm{pH}$. Plant pigment and protein level was reduced in sample collected from polluted areas. The pheophytin a and $b$ and peroxidase activity was enhanced in leaves of polluted area due to increased stress level and microbial diversity was reduced near industrial areas.
\end{abstract}

Key words: Pollution, Biochemical parameters, water quality, soil quality, microbial diversity

\section{Introduction}

Water, soil and vegetation are the valuable resources of nature on which humans, animals and other life form directly or indirectly depend for their living. The purity of these natural resources is essence for the healthy living. For the socioeconomic development of nation industrialization plays a vital role, but the increased pace of industrialization has put these natural resources to serious threat and ultimately posing threat to living being (Tiwari et al., 2008).The waste and pollutants from industries affect soil, water and vegetation equally. The release of pollutants and waste differs from industry to industry. For e.g. Leather industry waste is mainly composed of chromium, zinc , copper, sulphides, carbonates, sodium and many other toxic organic compounds and inorganic compounds Pulp industry mainly contain carbohydrates, textile industry contain dyes, plating industry contain nickel (Nouri et al., 2009). These pollutants not only alter the quality of soil and ground water but also pose serious problems (Karthikeyan et al., 2010).The altered ambient environment due to the intrusion of air pollutants in urban area is exerting a profound

Author's Address

Department of Biotechnology, G. B. Pant Engineering College Pauri-Garhwal Uttarakhand

E-mail:mamtabaunthiyal@yahoo.co.in influence on the morphological, biochemical and physiological status of plants. Oxides of Nitrogen, Sulphur are released in all types of combustion as they are formed by the oxidation of atmospheric nitrogen and sulphur at high temperature (Shyam et al., 2008).Air pollutants either alone or in combination with other pollutants influences plant physiology. The effect of these pollutants can be directly visualized by anatomical damages to leaflets such as darkening at the adaxial face and a wide brownish necrosis. Biochemical changes due to exposure of plants to various pollutants can be used as suitable bio monitoring tool to evaluate the impact of pollution in a particular area. For example peroxidase enzyme is used as an air pollution marker enzyme as its activity varies with the species of trees, season and concentration of pollutant (Yadav et al., 2013, Shyam et al., 2008).

Water used in industries creates a waste that has potential hazard for our environment because of the introduction of various contaminants such as heavy metals into soil and water resources (Bichi and Bello, 2013). Metal pollutants can easily enter the food chain if heavy metals contaminated soils are used for the production of crops (Verma and Dwivedi, 2013).The accumulation of metals in an aquatic environment have direct consequences to 
man and ecosystem. The present study was conducted to determine the impact of industrial pollution on water, soil and vegetation.

\section{Material and Methods}

Study area and sample collection:

The study areas were two cities of Uttarakhand, India. First wasDehradun situated between latitudes $29^{\circ} 58^{\prime} \mathrm{N}$ and $31^{\circ} 2{ }^{\prime} \mathrm{N}$ and longitudes $77^{\circ} 34^{\prime} \mathrm{E}$ and $78^{\circ} 18^{\prime} \mathrm{E}$ and second Kotdwara situated between latitudes $29^{\circ} 45^{\prime} 0 \mathrm{~N}$ and $31^{\circ} 2 \mathrm{~N}$ and longitudes $78^{\circ}$ $31^{\prime} 48 \mathrm{E}$. The main industrial area of Dehradun was Selaqui, which is also known as pharmacity as it contains most of the pharmaceutical industries. In Kotdwara the main industrial area is Balbhadrapur the place is popularly known as Sigaddi growth centre.

\section{Botanical Sampling:}

Leave of Rosa amblyotis, Murraya koenigii, Morinda citrifolia Linn. from Kotdwara region and Tagetes minuta, Rosa amblyotis, Brassica nigra from Dehradun region were randomly collected for estimating the vegetation damage due to pollutants. Two sampling sites were chosen as polluted site 1 and polluted site 2, the details of which are presented in Table 1 and Table 2. For control, leaves of these plants were collected $2 \mathrm{Km}$ away from the polluted site.

\section{Water Sampling:}

For water analysis, two sampling sites were chosen one for control and other as polluted site from both the cities. Water Samples from different sites were collected in the plastic cane of 2.5 litre, about $1 / 2$ litre water samples was collected from one hand pump from one site and these were mixed to get one sample from one site. In this way sample collected were analyzed in 2-3 days so no special preservation required.

\section{Soil Sampling:}

For soil sampling composite sampling was done, where sub-samples were collected from randomly selected locations in a field, and the subsamples are composited for analysis. The soil samples were then air dried and tested in laboratory.

\section{Methodology:}

For studying the impact of industrialization on vegetation, the commonly found plant species near the industrial site was chosen and following parameters were compared between control site and industrial site: Chlorophyll a and b, pheophytin and carotenoid was estimated using Arnon method (Arnon 1949). Protein content using Lowry method (Lowry et al., 1951) and Peroxidase activity using methodology of Puccinelli and Bragloni (Puccinelli and Bragloni, 1998).For water quality analysis around control and industrial site various water parameters like Total dissolved solids (TDS), Turbidity, pH, Alkalinity, Fluoride, Chloride and Total hardness were analyzed using water testing kit.For assessing the impact of industrialization on soil, soil $\mathrm{pH}$ was measured and number of microbial activity determined by plate count method, around control and industrial site.

\section{Results and Discussion \\ Effect of industrialization on water Quality}

Ground water is the prime source of drinking water in India. The quality of drinking water in Indian cities has been deteriorated in the recent years mainly due to growth of population and increased level of pollution in cities (Venkatasubramani, 2007). For assessing the quality of water for drinking purpose in these two cities various water parameters were tested and compared with values of ISI.The value of $\mathrm{pH}$ in control and industrial site of Kotdwara was same but in case of Dehradun $\mathrm{pH}$ varied from control to industrial from 7.5 to $6 . \mathrm{pH}$ value in both the cities was within desirable limit of 6.5-8.5. The value of $\mathrm{pH}$ was in accordance with the alkalinity value, which decreased from control site to industrial site of Dehradun i.e from $200 \mathrm{mg} / \mathrm{l}$ to $100 \mathrm{mg} / \mathrm{l}$ and in case of Kotdwara it was $200 \mathrm{mg} / \mathrm{l}$ in control site and $150 \mathrm{mg} / \mathrm{l}$ in industrial site. The desirable limit of TDS is $300 \mathrm{mg} / \mathrm{l}$ but in both the cities the TDS value was greater than desirable in both control and industrial site. But from control to industrial there was increase of TDS value from $692 \mathrm{mg} / \mathrm{L}$ to $750 \mathrm{mg} / \mathrm{l}$ in Kotdwara and $698 \mathrm{mg} / \mathrm{l}$ to $780 \mathrm{mg} / \mathrm{l}$ in Dehradun which indicates that increased pollution by extraneous sources can adversely affects the quality of water. The value of Turbidity was 0 NTU in both control and industrial which is desirable. The total hardness which is mainly caused due to calcium and magnesium salts were within the desirable limit of less than 300 ppm. The desirable limit of chloride according to ISI is $250 \mathrm{ppm}$ and in both cities the value of chloride decreased from control to industrial site 
Table1. Detail of sample location collected from Kotdwara

\begin{tabular}{|l|l|l|l|}
\hline Sample Source & Sample ID & Latitude & Longitude \\
\hline A. Botanical samples & KRS-1 (site 1) & $29.472124^{\circ}$ & $78.245518^{\circ}$ \\
\hline 1. Rosa amblyotis $(\mathrm{RA}(\mathrm{K}))$ & KRS-2 (site 2) & $29.472124^{\circ}$ & $78.245518^{\circ}$ \\
\hline 2. Rosa amblyotis (RA(K)) & KRC (control) & $29.472806^{\circ}$ & $78.259603^{\circ}$ \\
\hline 3. Rosa amblyotis (RA(K)) & KMS-1 (site 1) & $29.472124^{\circ}$ & $78.245518^{\circ}$ \\
\hline 4. Morinda Citrifolia Linn.(MC) & KMS-2 (site 2) & $29.472124^{\circ}$ & $78.245518^{\circ}$ \\
\hline 5. Morinda Citrifolia Linn. (MC) & KMC (control) & $29.472806^{\circ}$ & $78.259603^{\circ}$ \\
\hline 6. Morinda Citrifolia Linn. (MC) & KCS-1 (site 1) & $29.472124^{\circ}$ & $78.245518^{\circ}$ \\
\hline 7. Murraya koenigii (MK) & KCS-2 (site 2) & $29.472124^{\circ}$ & $78.245518^{\circ}$ \\
\hline 8. Murraya koenigii (MK) & KCC (control) & $29.472806^{\circ}$ & $78.259603^{\circ}$ \\
\hline 9. Murrayakoenigii (MK) & KWS (sample) & $29.472124^{\circ}$ & $78.245518^{\circ}$ \\
\hline B. Water Sample and Soil Sample & KWC (control) & $29.472806^{\circ}$ & $78.259603^{\circ}$ \\
\hline 1. Under ground Water & KSC (control) & $29.472806^{\circ}$ & $78.259603^{\circ}$ \\
\hline 2. Under ground water & KSS (sample) & $29.472124^{\circ}$ & $78.245518^{\circ}$ \\
\hline 3.Soil Sample & 4.Soil Sample
\end{tabular}

Table 2. Detail of sample location collected from Dehradun.

\begin{tabular}{|c|c|c|c|}
\hline Sample Source & Sample ID & Latitude & Longitude \\
\hline \multicolumn{4}{|l|}{ A. Botanical samples } \\
\hline 1. Rosa amblyotis (RA (D) & DRS-1 & $30.364452^{\circ}$ & $77.858186^{\circ}$ \\
\hline 2. Rosa amblyotis (RA (D) & DRS-2 & $30.364452^{\circ}$ & $77.858186^{\circ}$ \\
\hline 3. Rosa amblyotis(RA (D) & (control) & $30.348341^{\circ}$ & $77.890194^{\circ}$ \\
\hline 4. Tagetes minuta $(\mathrm{TM})$ & DMAS-1 & $30.364452^{\circ}$ & $77.858186^{\circ}$ \\
\hline 5. Tagetes minuta $(\mathrm{TM})$ & DMAS-2 & $30.364452^{\circ}$ & $77.858186^{\circ}$ \\
\hline 6. Tagetes minuta (TM) & (control) & $30.348341^{\circ}$ & $77.890194^{\circ}$ \\
\hline 7. Brassica nigra $(\mathrm{BN})$ & DMUS-1 & $30.364452^{\circ}$ & $77.858186^{\circ}$ \\
\hline 8. Brassica nigra $(\mathrm{BN})$ & DMUS-2 & $30.364452^{\circ}$ & $77.858186^{\circ}$ \\
\hline 9. Brassica nigra $(\mathrm{BN})$ & (control) & $30.348341^{\circ}$ & $77.890194^{\circ}$ \\
\hline \multicolumn{4}{|l|}{ B. Water and Soil Sample } \\
\hline 1. Underground water & (sample) & $30.364452^{\circ}$ & $77.858186^{\circ}$ \\
\hline 2. Underground Water & (control) & $30.348341^{\circ}$ & $77.890194^{\circ}$ \\
\hline 3.Soil sample & (control) & $30.348341^{\circ}$ & $77.890194^{\circ}$ \\
\hline 4.Soil Sample & (sample) & $30.364452^{\circ}$ & $77.858186^{\circ}$ \\
\hline
\end{tabular}

but was within the desirable limit. But fluoride content in both the cities were below the desirable limit which make it unfit for drinking purpose. The value of fluoride was $0 \mathrm{ppm}$ in both the control and sampling site of both the cities.

\section{Effect of industrialization on soil Quality}

For assessing the impact of industrial pollution on soil, the soil $\mathrm{pH}$ and microbial growth from the soil sample was analyzed. Soil $\mathrm{pH}$ or soil reaction is an indication of the acidity or alkalinity of soil and is measured in $\mathrm{pH}$ units. As shown in table 4 the soil $\mathrm{pH}$ was found to be lower in industrial area of both the cities as compared to control site. The soil with $\mathrm{pH}$ greater than 8.5 is generally called as sodic soil. But $\mathrm{pH}$ of all soils samples are less than 8.5 indicating that soil samples are free from sodicity hazards. The decrease in $\mathrm{pH}$ could be due to the decreased amount of carbonate and bicarbonate (Sonawane, 2010).

\section{1}


Table 3: Effect of industrialization on water quality

\begin{tabular}{|l|c|c|c|c|}
\hline \multirow{2}{*}{ Parameter } & KOTDWARA. & \multicolumn{2}{l|}{ DEHRADUN } \\
\cline { 2 - 5 } & KWC & KWS & DWC & DWS \\
\hline TDS (gm) & 0.6924 & 0.7502 & 0.6986 & 0.7894 \\
\hline Turbidity & 0.0 & 0.0 & 0.0 & 0.0 \\
\hline pH & 7.0 & 7.0 & 7.5 & 6.6 \\
\hline Alkalinity (in ppm) & 200 & 150 & 200 & 100 \\
\hline Fluoride (in ppm) & 0.0 & 0.0 & 0.0 & 0.0 \\
\hline Chloride (in ppm) & 78 & 115 & 69 & 92 \\
\hline Total hardness (in ppm) & 300 & 210 & 140 & 175 \\
\hline
\end{tabular}

Table 4: Effect of industrialization on soil pH

\begin{tabular}{|c|l|l|c|c|}
\hline \multirow{2}{*}{ Dilution } & \multicolumn{2}{|l|}{ KOTDWARA } & \multicolumn{2}{l|}{ DEHRADUN } \\
\cline { 2 - 5 } & KSC & KSS & DSC & DSS \\
\hline $1: 2$ & 6.1 & 6.1 & 6.9 & 6.4 \\
\hline $2: 1$ & 7.0 & 6.2 & 6.8 & 6.5 \\
\hline $1: 1$ & 7.0 & 6.3 & 6.7 & 6.6 \\
\hline
\end{tabular}

Table 5. Microbial growth observed for soil sample.

\begin{tabular}{|l|l|l|l|l|}
\hline \multirow{2}{*}{$(\mathbf{c f u} / \mathbf{g})$} & DEHRADUN & \multicolumn{2}{l|}{ KOTDWARA } \\
\cline { 2 - 5 } & DSC & DSS & KSC & KSS \\
\hline Total bacterial count $\left(10^{-6}\right)$ & 56 & 16 & 700 (approx.) & 175 \\
\hline Total fungal count $\left(10^{-6}\right)$ & 3 & 00 & 3 & 0 \\
\hline Total viability $\left(10^{-6}\right)$ & 59 & 16 & 703 (approx.) & 175 \\
\hline
\end{tabular}

But overall the $\mathrm{pH}$ value of soil was within favorable value neither too high (more than 8.5) nor too low. The samples were analyzed for microbial growth and it was observed as shown in table 5, that there was reduction in the growth of microorganisms at different dilution in both the industrial sites as compared to control site. The $\mathrm{pH}$ between 6-8 is favorable for bacterial growth therefore in comparison to fungus bacterial count was found higher in all the samples. The decrease in number of microorganism both fungus and bacteria near industrial site as compared to control site may be attributed to altered $\mathrm{pH}$ of soil and water quality condition in control and industrial site.

Effect of industrialization on biochemical parameters of plants:

A profound impact of industrialization on different vegetations was noted in both the cities. In the samples of Rosa amblyotis, Murraya koenigii and Morinda Citrifolia Linn. from Kotdwara region and samples of Tagetes minuta,Rosa amblyoti, Brassica nigra from Dehradun region, it was observed that the pigment chlorophyll $\mathrm{a}$ and $\mathrm{b}$, carotenoid, and protein content measured in $\mathrm{mg} / \mathrm{gm}$ in leaves sample of plant species were reduced in sample of industrial site as compared to sample from control site. In contrast Pheophytin a and b and Peroxidase activity was increased in the sample of industrial site as compared to samples from control site.Being the main core of energy production in green plants the amount of chlorophyll is changed by the effect of environment on plant metabolism and exposing of plants to above the acceptable range of pollutants, photosynthesis gets slowed down. As chlorophyll play an important role in plant metabolism the measurement of chlorophyll content may be an important tool to evaluate effect of industrial pollution on plant (Joshi et al., 2009). Similarly Carotenoids protect photosynthetic organisms against potentially harmful photoxidative processes and are essential structural components of the photosynthetic antenna and reaction center (Joshi and Swami, 2009). In the present study amount of chlorophyll was decreased in leaves sample of all plants of industrial area as shown in fig. 1. 
Ecological damage in the vicinity of two
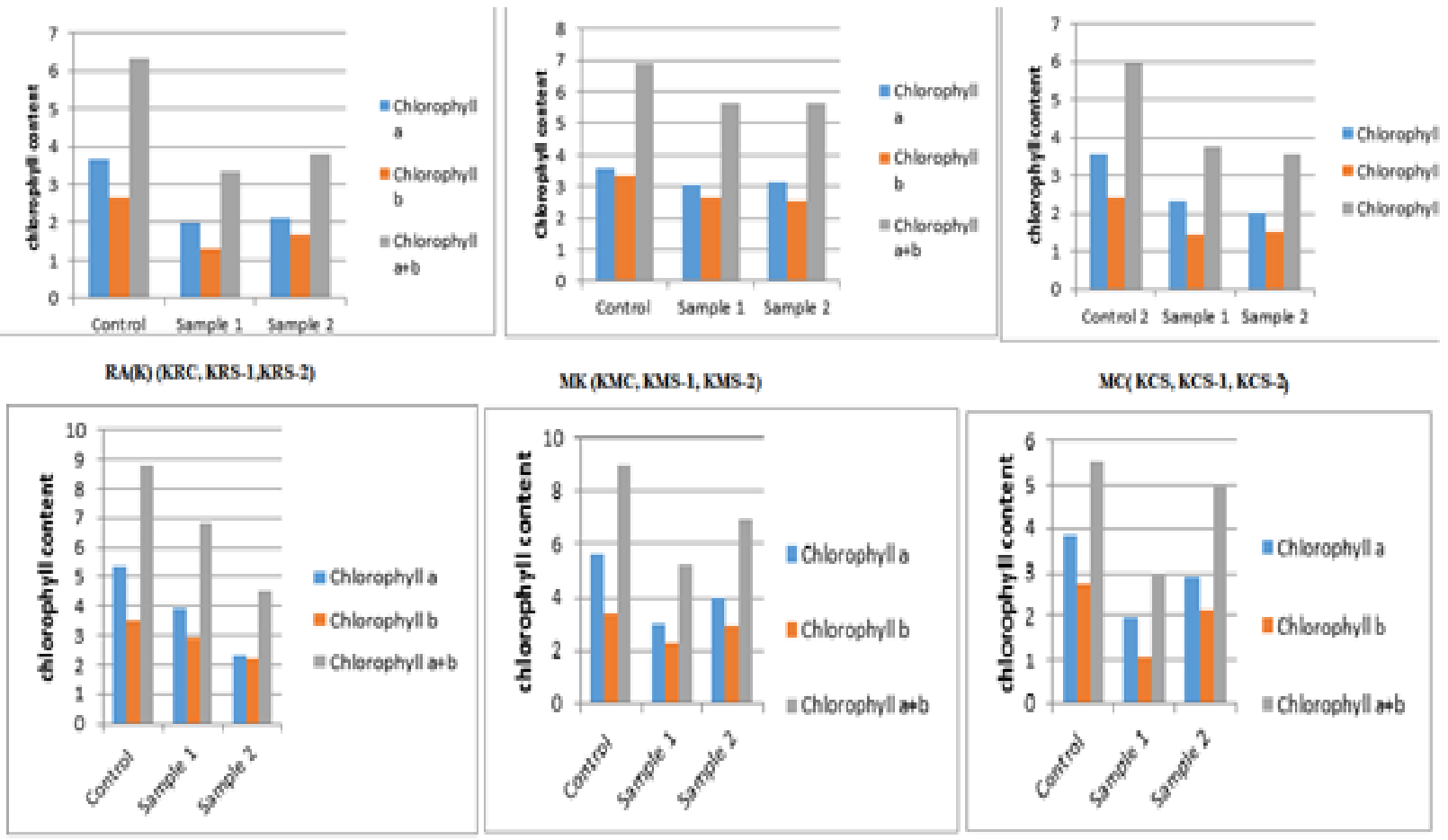

BN (DBC, DBS-1,DBS-2)

IM(DTC, DTS-1.DTS-2)

RA (DRC, DRS-1,DRS-2)

Fig.1. Concentration of Chlorophyll mg/gm wt. of leaves

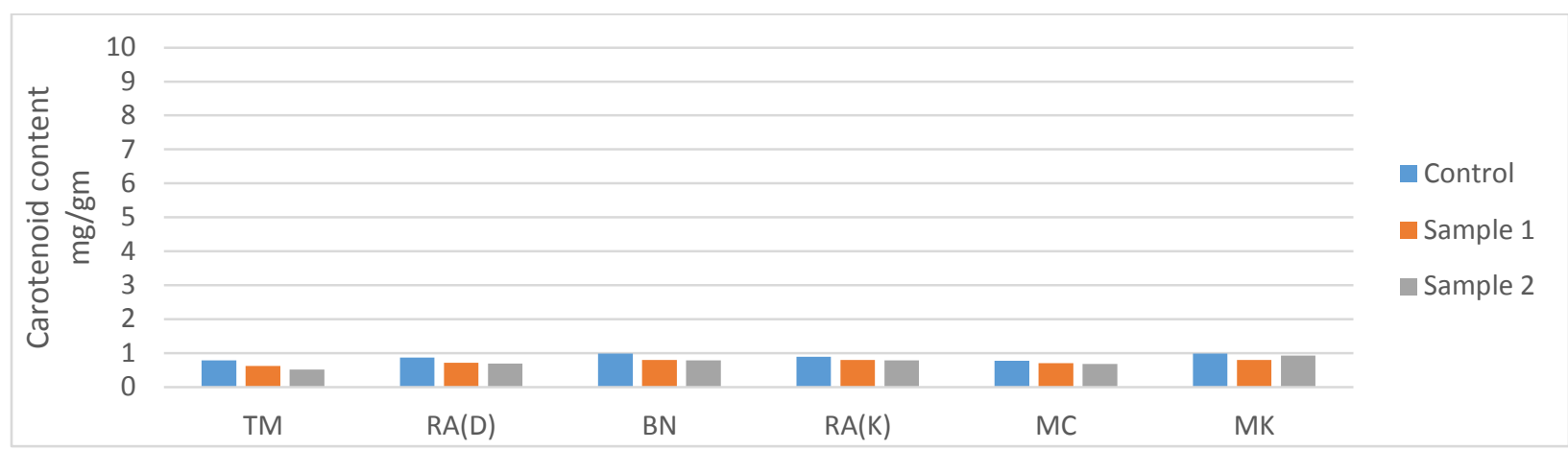

Fig.2 Concentration of carotenoid in $\mathrm{mg} / \mathrm{gm}$ wt. of leaves

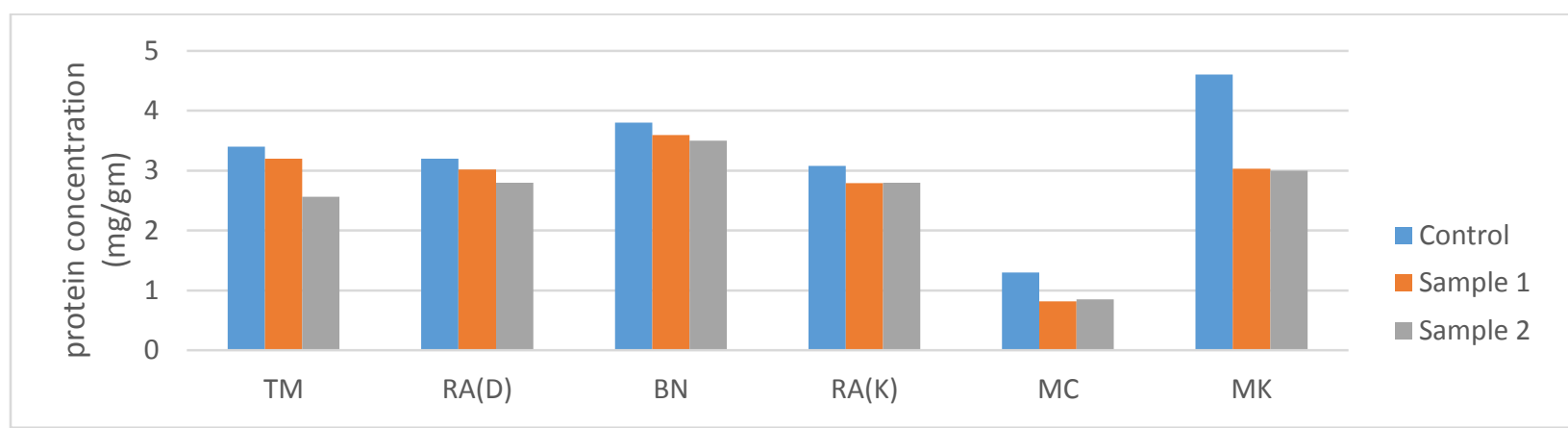

Fig.3. Concentration of Protein in mg/gm wt. of leaves 


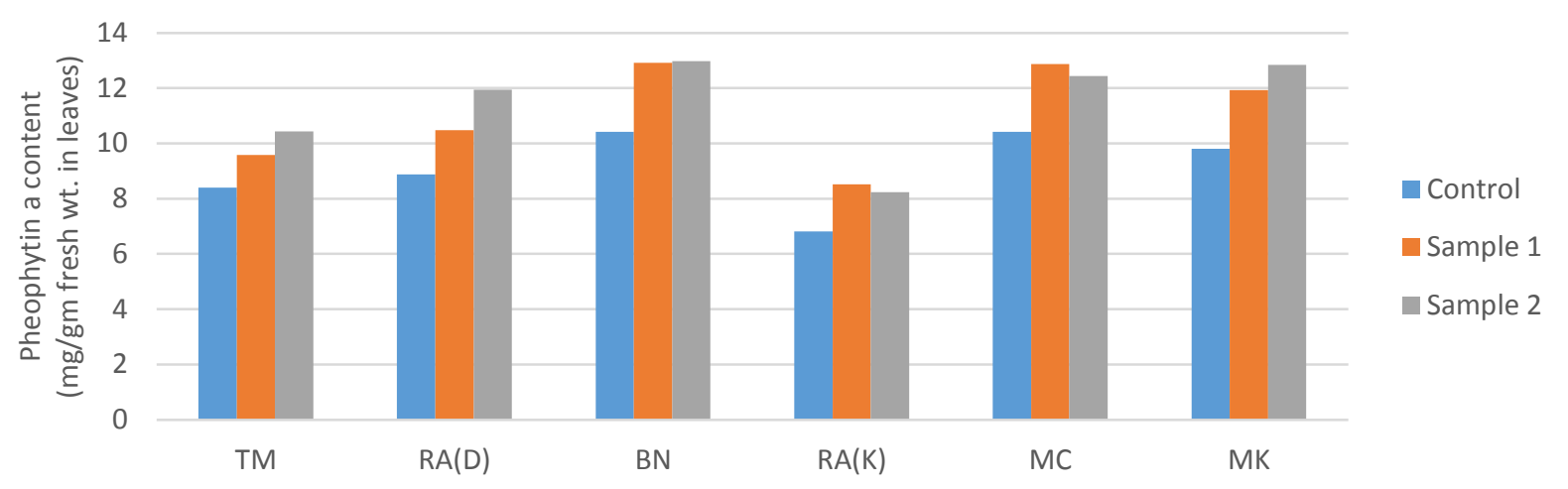

Fig. 4 a.Concentration of Pheophytin a in $\mathrm{mg} / \mathrm{gm}$ wt. of leaves

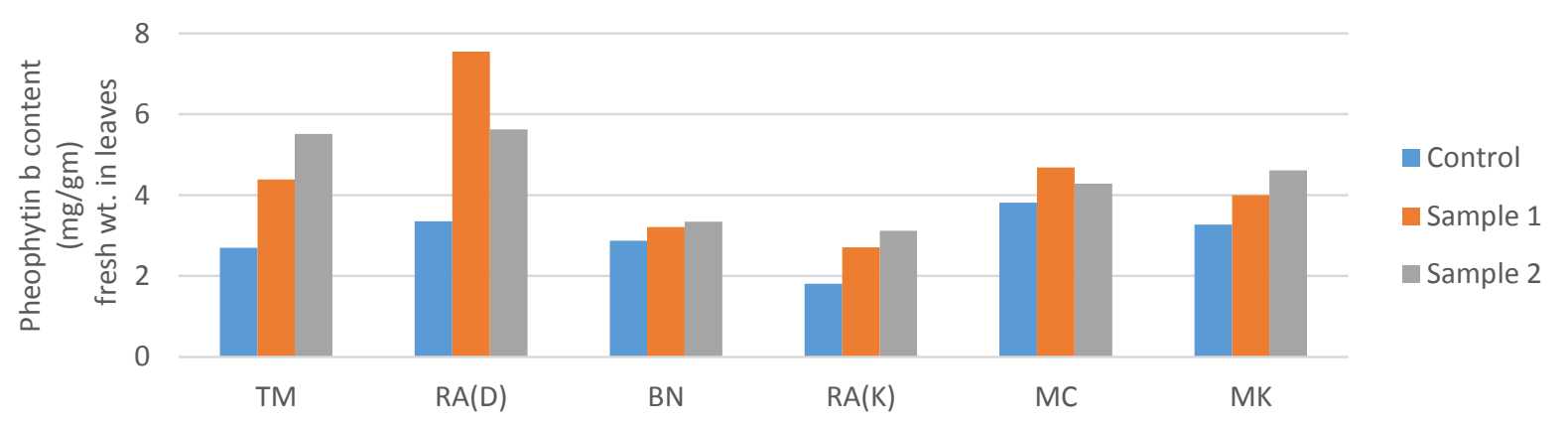

Fig. 4 b.Concentration of Pheophytin b in $\mathrm{mg} / \mathrm{gm}$ wt. of leaves

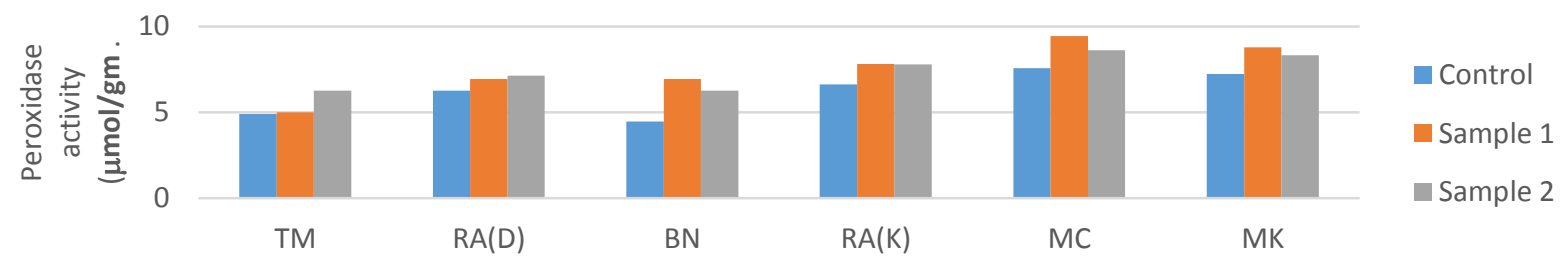

Fig. 5. Activity of Peroxidase in $\mu \mathrm{mol} / \mathrm{gm}$ wt. of leaves

Similar decreased pattern was recorded by many researchers in different plants (Verma and Chandra 2014, Seyyednejad 2013, Yadav et al., 2013). Among all the sample maximum reduction in total chlorophyll content was shown by Rosa amblyotis plant of Kotdwara region in which total chlorophyll content was $6.349 \mathrm{mg} / \mathrm{gm}$ in control site and 3.343 $\mathrm{mg} / \mathrm{gm}$ and $3.798 \mathrm{mg} / \mathrm{gm}$ in polluted site 1 and site 2 respectively. Similarly in Dehradun region Brassica nigra showed the maximum reduction of $8.829 \mathrm{mg} / \mathrm{gm}$ in control site and $4.25 \mathrm{mg} / \mathrm{gm}$ in polluted site 2. In case of carotenoids as shown in fig. 2 not much variation was observed, but there was a decrease in value from control to polluted site. Reduced protein content among sample of polluted site may be due to enhanced rate of protein denaturation and break down of existing protein to amino acid or reduced denovo synthesis of protein (Rai and Panda, 2015). Murraya koenigii sample from Kotdwara region showed maximum decrease in protein content, in which control sample showed $4.5 \mathrm{mg} / \mathrm{gm}$ and polluted site 1 and 2 showed near to $3.0 \mathrm{mg} / \mathrm{gm}$ as shown in fig. 3 .

Pheophytin play a major role in Photosystem. In contrast to chlorophyll a and $b$, increase level of Pheophtyin in polluted site in comparison to control site was observed as shown in fig. $4 \mathrm{a}$ and $4 \mathrm{~b}$. It might be due to the breakdown of chlorophyll to Pheophytin (Yadav et al., 2013). The level of Pheophytin indicates the sensitivity of plants to the 
pollutants; the higher the Pheophytin level in the plant is, the greater the plant is sensitive to air pollution (Verma and Chandra, 2014). Amongst the entire plant samples, Rosa amblyotis showed the maximum increase in Pheophytin $b$ level in the polluted site of both cities. In case of Kotdwara in control sample value was $1.810 \mathrm{mg} / \mathrm{gm}$ as compared to polluted site1 and 2 values 2.71 $\mathrm{mg} / \mathrm{gm}$ and $3.12 \mathrm{mg} / \mathrm{gm}$ respectively. Similarly Rosa amblyotis of Dehradun showed increase from $3.348 \mathrm{mg} / \mathrm{gm}$ in control site to $7.546 \mathrm{mg} / \mathrm{gm}$ in polluted site1.

Being an antioxidant enzyme and effective quencher of reactive oxygen species, peroxidase plays an important role for plant survival and adaption during stress condition. The activity of peroxidase was found to increase in polluted site as compared to control site in all samples as shown in fig 5 . Increase in peroxidase activity could be due to reduction in chlorophyll content as it play important role in chlorophyll degradation (Selvaraj, 2013).Among all sample maximum increase was found in Morinda citrifolia of Kotdwara region which was $7.57 \mu \mathrm{mol} / \mathrm{gm}$ in control site and 9.4339 $\mu \mathrm{mol} / \mathrm{gm}$ in site 1 and $8.620 \mu \mathrm{mol} / \mathrm{gm}$ in site 2 . And in case of Dehradun region Brassica nigra showed maximum increase from $4.464 \mu \mathrm{mol} / \mathrm{gm}$ in control site to $6.944 \mu \mathrm{mol} / \mathrm{gm}$ in site 1 and 6.250 $\mu \mathrm{mol} / \mathrm{gm}$ in site 2. Many studies have suggested that Peroxidase is a specific indication of $\mathrm{SO}_{2}$ and $\mathrm{NO}_{2}$ pollution (Rai and Panda, 2015).

\section{Conclusion}

Sampling and analysis of plants, soil, water is valuable to determine the physio-chemical parameters of the micro environment around the industries. The study concluded that the overall pigment and protein degradation were observed near industrial area and peroxidase activity and pheophytin values were found higher as compared to control, which may be due to temperature variations and presence of pollutants such as organic gases $\left(\mathrm{SO}_{2}, \mathrm{NO}_{\mathrm{X}}\right)$. These changes in plants are biological compensatory responses to environmental stress. Among various parameters of water quality; chloride and TDS was found to be higher around the industries. Talking about ecological study the population density of plants and microbes were found less around industrial sites which shows that there is an impact of industries on population density of organisms and plants. Soil, water and biodiversity are essential elements of ecosystem and are the subject of many agricultural, ecological, biological and hydrological studies, since large amounts of chemicals enter animal and human food chain through cultivated contaminated soils and water. The study concludes that there is a need to access the ecological risk associated with the polluted areas and necessary action must be taken in this direction.

\section{Acknowledgement}

The authors acknowledge Swajal project, Puari Garhwal, Uttarakhand for providing field test kit for the present study.

\section{References}

Tiwari K.K., Dwivedi S., Mishra S., 2008. Phytoremediation efficiency of Portulaca tuberose sox and Portulaca oleracea L. naturally growing in an industrial effluent irrigated area in Vadodara, Gujarat. India. Enviorn Monit Assess, 147: 15-22.

Nouri J., Khorasani N., Lorestani B., 2009. Accumulation of heavy metals in soil and uptake by plant species with phytoremediation potential. Environ Earth Sci, 59: 315323.

Karthikeyan K., Chandran C., Kulothangan S., 2010. Biodegradation of oil sludge of petroleum waste from automobile service station using selected fungi. $\boldsymbol{J}$ Ecotoxicol Environ Monit, 20(3): 225-230.

Shyam S., Nath K., Singh D., 2008. Harmful effects of air pollutants in biochemical parameters of plants. Res Environ Life Sci, 1(2):65-68

Yadav S.K., Singh M.M., and Kumar V., 2013. Effect of Air Pollutants in Biochemical Parameters of Selected Plant Species of Jhansi City (Uttar Pradesh). IJETCAS, 6(2):168-173.

Bichi M.H., Bello U.F., 2013. Heavy metal Pollution in surface and ground waters used for irrigation along river Tatsawarki in The Kano, Nigeria. IOSR Journal of Engineering, 3(8):1-09.

Verma R., Dwivedi P., 2013. Heavy metal water pollution- A case study. Recent Res Sci Tech, 5(5): 98-99.

Arnon D.I, 1949.Copper enzymes in isolated chloroplast polyphenol oxidase in Beta vulgaris. Plant Physiol, 24: 115. 
Lowry O.H., Rosebrough N.J., Farr A.L., and Randall R.J., 1951. Protein measurement with folin phenol reagent. $J$ Biol Chem, 193:265-275.

Puccinelli N.A., Bragloni M, 1998. Peroxidase: Usable markers of air pollution in trees from urban environments. Chemosphere, 36: 889-894.

Venkatasubramani R., Meenambal T., Livingston P., Goldwyn.,2007.Ground water quality of Palladam Taluk, Coimbatore district, Tamilnadu. J Ecotoxicol Environ Monit, 17(1): 85-90.

Sonawane D.V., Lawande S.P., Gaikwad V.B., and Kuchekar S.R., 2010. Impact of Industrial Waste Water on Soil Quality And Organic Matter Around Kurkumbh Industrial Area Daund, Pune District. Int J Chem Sci 8(1): 97-102.

Joshi N., Chauhan A., and Joshi P.C., 2009. Impact of industrial air pollutants on some biochemical parameters and yield in wheat and mustard plants. Environmentalist, 29: $398-404$
Joshi P.C., Swami A., 2009. Air pollution induced changes in the photosynthetic pigments of selected plant species. $\boldsymbol{J}$ Environ Boil, 30(2): 295-298.

Verma V., Chandra N., 2014. Biochemical and Ultrastructural Changes in Sida cordifolia L. and Catharanthus roseus L. to Auto Pollution. Int Sch Res Notices, Volume 2014, Article ID 263092, 11 pages.

Seyyednejad S.M., Koochak H., Vaezi J., 2013. Some biochemical responses due to industrial air pollution in Prosopis juliflora plant. Afr J Agric Res, 2(10): 471-481.

Rai P.K., Panda L.S., 2015. Roadside plants as bio indicators of air pollution in an industrial region, Rourkela, India. IJOART, 4(1):17-35

Selvaraj K., Sevugaperumal R., Ramasubramanian V., 2013. Impact of Match Industry Effluent on Growth and Biochemical Characteristics of Cyamopsis Tetragonoloba Taub and Amelioration of the stress by seaweed treatment. Ind J Fund Appl Life Sci, 3 (1):192-197. 